\title{
Herbicide Inputs and Mowing Affect Vaseygrass (Paspalum urvillei) Control
}

\author{
Matthew D. Jeffries, Travis W. Gannon, and Fred H. Yelverton*
}

\begin{abstract}
Vaseygrass is an invasive, perennial $\mathrm{C}_{4}$-grass commonly found on roadsides in areas with poorly drained soils. Due to its upright growth habit and seedhead production, vaseygrass can impair motorist sightlines and subsequently, require increased management inputs to maintain vegetation at an acceptable height. Two field experiments were conducted from 2012 to 2015 on North Carolina roadsides to evaluate the effect of mowing and mowing timing with respect to applications of various herbicides on vaseygrass control. Both experiments evaluated clethodim $\left(280 \mathrm{~g}_{\text {ai }} \mathrm{ha}^{-1}\right)$, foramsulfuron + halosulfuron + thiencarbazone-

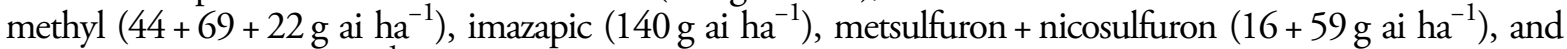
sulfosulfuron $\left(105 \mathrm{~g} \mathrm{ai} \mathrm{ha}^{-1}\right)$ with a nonionic surfactant at $0.25 \% \mathrm{v} / \mathrm{v}$. Experiment one focused on the effect of mowing (routinely mowed or nonmowed) and herbicide application timing (fall-only, fall-plus-spring, or spring-only), while experiment two focused on pre-herbicide application mowing intervals $(6,4,3,2,1$, or $0 \mathrm{wk}$ before treatment [WBT]). From experiment one, routine mowing reduced vaseygrass cover in nontreated plots $55 \%$ at $52 \mathrm{wk}$ after fall treatment (WAFT), suggesting this cultural practice should be employed where possible. Additionally, routine mowing and herbicide application season affected herbicide efficacy. Treatments providing $>70 \%$ vaseygrass cover reduction at 52 WAFT included routinely mowed fall-only clethodim and fall-plus-spring imazapic, and fall-plus-spring metsulfuron + nicosulfuron across mowing regimens. Within clethodim, mowing vaseygrass 2 or 1 WBT resulted in the lowest cover at 40 (1 to $2 \%$ ) and 52 (4 to 6\%) wk after treatment (WAT) compared to other intervals, which aligns with current label vegetation height at treatment recommendation. Vaseygrass persisted across all treatments evaluated through 52 WAT, suggesting eradication of this species will require inputs over multiple growing seasons.
\end{abstract}

Nomenclature: Clethodim; foramsulfuron; halosulfuron; imazapic; metsulfuron; nicosulfuron sulfosulfuron; thiencarbazone; vaseygrass, Paspalum urvillei Steud.

Key words: Herbicide application timing, integrated weed management, invasive plant, roadside vegetation management, turfgrass.

Paspalum urvillei es una gramínea $\mathrm{C}_{4}$ perenne invasiva que se encuentra comúnmente a las orillas de caminos y en áreas con suelos con poco drenaje. Debido a su hábito de crecimiento vertical y producción de espigas, $P$. urvillei puede limitar la visibilidad de vehículos y subsecuentemente incrementar los insumos de manejo para mantener la vegetación a una altura aceptable. Se realizaron dos experimentos de campo desde 2012 a 2015 en orillas de caminos en North Carolina para evaluar los efectos de la chapia y el momento de chapia con respecto a las aplicaciones de varios herbicidas sobre el control de $P$. urvillei. Ambos experimentos evaluaron clethodim $\left(280 \mathrm{~g}\right.$ ai ha $\left.{ }^{-1}\right)$, foramsulfuron + halosulfuron + thiencarbazone-methyl $\left(44+69+22 \mathrm{~g}\right.$ ai ha $\left.^{-1}\right)$, imazapic $\left(140 \mathrm{~g}\right.$ ai ha $\left.{ }^{-1}\right)$, metsulfuron + nicosulfuron $\left(16+59 \mathrm{~g}^{\text {ai ha }} \mathrm{ha}^{-1}\right)$, y sulfosulfuron $\left(105 \mathrm{~g}\right.$ ai ha $\left.{ }^{-1}\right)$ con un surfactante no iónico a $0,25 \% \mathrm{v} / \mathrm{v}$. El experimento uno se enfocó en el efecto de la chapia (chapia rutinaria o sin chapia) y el momento de aplicación de herbicidas (sólo otońo, otoño más primavera, o sólo primavera), mientras que el experimento dos se enfocó en el intervalo entre la chapia y la aplicación de herbicidas (6, 4, 3, 2, 1, ó 0 semanas antes del tratamiento [WBT]). En el experimento uno, la chapia rutinaria redujo 55\%la cobertura de P. urvillei en parcelas sin tratamiento con herbicidas a 52 semanas después del tratamiento de otońo (WAFT), sugiriendo que esta práctica cultural debería ser empleada cuando sea posible. Adicionalmente, la chapia rutinaria y la temporada de aplicación de herbicida afectaron la eficacia del herbicida. Los tratamientos que proveyeron $>70 \%$ de reducción en la cobertura de $P$. urvillei a 52 WAFT incluyeron chapia rutinaria y clethodim sólo en el otoño e imazapic en el otoño más la primavera, y metsulfuron + nicosulfuron en el otońo más la primavera para todos los regímenes de chapia. Dentro de los tratamientos con clethodim, la chapia 2 ó 1 WBT resultó en la menor cobertura a 40 (1 a 2\%) y 52 (4 a 6\%) semanas después del tratamiento (WAT) al compararse con otros intervalos, lo que se alinea con la actual recomendación de la etiqueta de tratamiento según la altura de la vegetación. $P$. urvillei persistió en todos los tratamientos evaluados hasta 52 WAT, lo que sugiere que la erradicación de esta especie requerirá insumos a lo largo de múltiples temporadas de crecimiento.

\footnotetext{
DOI: 10.1614/WT-D-16-00072.1

*Graduate Research Technician, Assistant Professor, and Professor, Department of Crop and Soil Sciences, North Carolina State University, Raleigh, NC 27695-7620. Corresponding author's E-mail: mdjeffri@ncsu.edu
} 
Roadside vegetation management is an arduous endeavor that requires a balance between providing safe travel routes and preserving road system infrastructure in an environmentally responsible manner (NCHRP 2005). Specific to motorist safety, one concern is vision impairment caused by excessive vegetation growth on road medians and shoulders. To mitigate vision impairment, roadsides are routinely mowed per local or state recommendations to provide clear definition of travel ways and adjacent areas (Ferrell et al. 2009; Minnesota Department of Transportation 2008; Zartman et al. 2013). Mowing recommendations take into consideration many management considerations; however, they largely relate to a maximum acceptable vegetation height, or intervention height, to avoid impairing motorist sightlines (Zartman et al. 2013). Maximum acceptable vegetation height typically varies from 15 to $45 \mathrm{~cm}$, and is costly to maintain (Louisiana Department of Transportation 2000; Ohio Turnpike Commission 2003; Zartman et al. 2013). A 2005 report summarizing roadside vegetation management practices in 21 US states found mowing expenses incurred by managing bodies varies widely, ranging from US\$50.93 $\mathrm{ha}^{-1}$ (Kentucky) to US\$462.53 $\mathrm{ha}^{-1}$ (Florida) for fine turfgrass areas (NCHRP 2005). From 2012 to 2015, North Carolina roadside mowing costs totaled US\$23,941,022 $\mathrm{yr}^{-1}$ (DC Smith, personal communication). While low-growing vegetation is typically established on roadside medians and shoulders for numerous reasons, including reduced mowing requirements, weed infestations can necessitate additional management inputs to maintain adequate motorist vision sightlines (Zartman et al. 2013).

Native to South America, vaseygrass (Paspalum urvillei Steud.) is an invasive, perennial $\mathrm{C}_{4}$-grass that grows throughout the southeastern United States and in California (USDA 2015). Vaseygrass commonly infests pastures, roadsides, and other grass systems, and predominately spreads via seed (Ansong et al. 2015; Bryson et al. 2009; USDA 2015). Due to its high tolerance of poorly drained soils, vaseygrass is well suited to grow in roadside areas that are not routinely mowed, such as ditches and low-lying guardrails (Newman et al. 2003; personal observation). Vaseygrass has an upright growth habit, reaches $2 \mathrm{~m}$ in height, and can require increased vegetation management efforts to mitigate impairment of motorist sightlines (Bryson et al. 2009; KC Clemmer, personal communication).
Published research to date pertaining to vaseygrass control is limited. Sanders et al. (2001) reported that imazapic $\left(67 \mathrm{~g}\right.$ ai $\mathrm{ha}^{-1}$ ) applied in May provided $>90 \%$ vaseygrass control. Vaseygrass control with other herbicides has received limited attention in the scientific literature. Cultural practices, including grass canopy height management and nitrogen inputs, affect vaseygrass growth (Newman et al. 2003; Newman and Sollenberger 2005). Newman et al. (2003) reported that vaseygrass cover decreased 9\% over $2 \mathrm{yr}$ when maintained at $20 \mathrm{~cm}$, while it increased $4 \%$ when maintained at $40 \mathrm{~cm}$. Newman and Sollenberger (2005) reported that vaseygrass cover decreased $15 \%$ when continuously grazed by cattle, but decreased 3\% when rotationally grazed. Additionally, coupling fertilizer inputs (50 kilograms nitrogen per hectare) with grazing at $15 \mathrm{~cm}$ reduced vaseygrass cover $16 \%$ compared to grazing at $30 \mathrm{~cm}$ (Newman and Sollenberger 2005). While fertilizing roadside vegetation is not feasible in most scenarios, herbicide applications and mowing are common control strategies that, if appropriately coordinated, may enhance vaseygrass control programs. The objectives of this research were to determine if vaseygrass control with various herbicides at fall and spring timings is affected by mowing and mowing timing.

\section{Materials and Methods}

Research Overview. The presented research includes two field experiments, with the latter building off of the former. Experiment one evaluated the effect of various herbicide treatments and application timings in plots routinely mowed or not mowed throughout the trial period. Based on results from run one of experiment one, which suggested that vaseygrass control was enhanced by fall herbicide applications and mowing, experiment two was initiated. Experiment two evaluated the same herbicide treatments as did experiment one, but used only fall herbicide applications and investigated the effect of mowing prior to herbicide application on vaseygrass control.

Experiment One. Field research was conducted from 2012 to 2014 on a roadside in Duplin County, North Carolina $\left(34^{\circ} 55^{\prime} 07.66^{\prime \prime} \mathrm{N}, 78^{\circ} 01^{\prime} 13.03^{\prime \prime W}\right)$ to evaluate the effect of mowing and herbicide application timing on vaseygrass control. Soil texture was a loamy fine sand, and the managed turfgrass was 
Table 1. Herbicides included in vaseygrass control research.

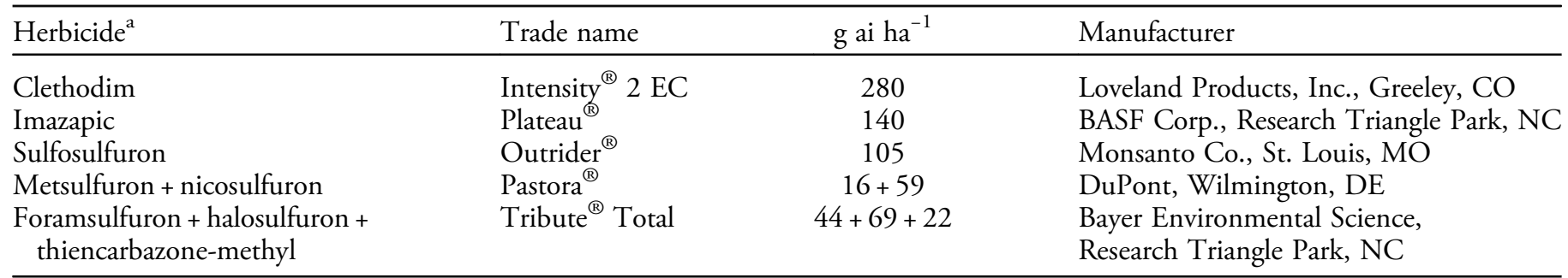

${ }^{\mathrm{a}}$ All herbicide applications included a nonionic surfactant at $0.25 \% \mathrm{v} / \mathrm{v}$.

centipedegrass [Eremochloa ophiuroides (Munro) Hack.]. Herbicides selected for this research (Table 1) are currently registered for use on roadsides for POST control of various dicot and monocot weeds (Anonymous 2011a, 2011b, 2011c, 2013, 2015); however, excluding imazapic and metsulfuron + nicosulfuron, current labeling does not mention vaseygrass. Based on previous, unpublished research, it was decided to include clethodim, foramsulfuron + halosulfuron + thiencarbazone, and sulfosulfuron in the experiments. Herbicide application timings included fall-only and fall-plus-spring in run one, as well as an additional spring-only timing in run two. Fall applications were made on October 16, 2012 and October 1, 2013 in runs one and two, respectively, while spring applications were made on June 17, 2013 and June 18, 2014 in runs one and two, respectively. Average vaseygrass cover at fall herbicide application was $43 \%$.

Prior to herbicide application in the fall, the entire trial area was mowed $(10 \mathrm{~cm}$ height of cut, debris removed) $6 \mathrm{wk}$ before treatment (WBT), at which time mowing ceased in nonmowed plots. Routinely mowed plots were cut to $10 \mathrm{~cm}$ throughout the trial period, from $6 \mathrm{WBT}$ to $52 \mathrm{wk}$ after fall treatment (WAFT), when average vegetation height in non-treated plots reached a $30-\mathrm{cm}$ maximum allowance. Although arbitrarily set, the $30-\mathrm{cm}$ maximum vegetation height allowance used in this research is also used in practice by numerous state departments of transportation, including Minnesota and Missouri (Minnesota Department of Transportation 2008; Missouri Department of Transportation 2003). Including the $6 \mathrm{WBT}$ cut, this totaled three fall mowing events in both experimental runs, and four (run one) and five (run two) spring-tofall mowing events the following growing season.

Herbicides were applied to plots measuring 1.8 by $3 \mathrm{~m}$ with a $\mathrm{CO}_{2}$-pressurized boom with four 11002 AIXR VS flat fan nozzles (TeeJet ${ }^{\circledR}$, Spraying Systems Co., Wheaton, IL) calibrated to deliver
$187 \mathrm{~L} \mathrm{ha}^{-1}$ at $179 \mathrm{kPa}$. All treatments included a nonionic surfactant: alkyl aryl polyoxylkane ethers, alkanolamides, dimethyl siloxane, or free fatty acids (Induce ${ }^{\circledR}$, Helena Chemical Co., Collierville, TN), at $0.25 \% \mathrm{v} / \mathrm{v}$.

Three replications of a factorial treatment arrangement evaluating mowing (routinely mowed or nonmowed), herbicide treatments (five herbicides), and application timings (fall-only or fall-plus-spring in runs one and two; spring-only in run two) were evaluated in a strip plot randomized complete block design. The whole plot factor was mowing, while subplots were combinations of herbicides (Table 1) and application timings. Mowed and nonmowed non-treated controls were included for comparison.

Experiment Two. Field research was conducted from 2013 to 2015 on a roadside in Craven County, North Carolina $\left(35^{\circ} 07^{\prime} 46.45^{\prime \prime} \mathrm{N}, 77^{\circ} 08^{\prime} 33.38^{\prime \prime} \mathrm{W}\right)$ to evaluate the effect of pre-herbicide application mowing interval on vaseygrass control. Soil texture was a silt loam, and the managed turfgrass was bahiagrass (Paspalum notatum Flueggé). Similarities between experiments one and two include mowing equipment, height of cut, and debris removal, as well as evaluated herbicides and nonionic surfactant inclusion.

The entire trial area was mowed 8 WBT and allowed to regrow for $2 \mathrm{wk}$ before the pre-herbicide application interval mowing commenced. Intervals evaluated included mowing $6,4,3,2,1$, or 0 WBT. Herbicides were applied $1 \mathrm{~h}$ after mowing at $0 \mathrm{WBT}$. Average vaseygrass cover at herbicide application was $58 \%, 52 \%, 45 \%, 35 \%, 28 \%$, and $27 \%$ following mowing $6,4,3,2,1$, and 0 WBT, respectively, while average height was $62,45,34,25,17$, and $11 \mathrm{~cm}$. Following herbicide application, plots were not mowed for the remainder of the growing season, and were only mowed one time the following season after the $40 \mathrm{wk}$ after treatment (WAT) data collection. 
Herbicide applications were made on September 18, 2013 and September 19, 2014 in runs one and two, respectively. Herbicides were applied to plots measuring 1.2 by $2.4 \mathrm{~m}$ with a $\mathrm{CO}_{2}$-propelled boom with three 8002 XR VS flat fan nozzles (TeeJet ${ }^{\circledR}$, Spraying Systems Co., Wheaton, IL) calibrated to deliver $187 \mathrm{~L} \mathrm{ha}^{-1}$ at $179 \mathrm{kPa}$. The aforementioned treatments were evaluated in unique research areas in each experimental run.

Three replications of a factorial treatment arrangement evaluating mowing interval $(6,4,3,2$, 1 , or 0 WBT) and herbicide treatment (five herbicides) were evaluated in a strip plot randomized complete block design. The whole plot factor was mowing interval, with herbicide treatment subplots. Non-treated controls were included for comparison.

Data Collection. In experiment one, vaseygrass cover was estimated visually on a $0 \%$ (no cover) to $100 \%$ (complete cover) scale at 2, 4, 8, 40, 46, and 52 WAFT. Data collection in experiment two also included visual cover estimations; however, data collection times varied due to earlier fall and no spring herbicide application timings. Additionally, the averages of three vaseygrass foliage height $(\mathrm{cm})$ measurements and seedhead counts (seedheads $\mathrm{m}^{-2}$ ) were recorded. Data collection occurred at 4 and 8 WAT until dormancy onset, and the following summer at 40, 46, and 52 WAT.

Statistical Analysis. Statistical analysis was conducted by ANOVA $(\mathrm{P}<0.05)$ using MIXED procedures in SAS $^{\circledR}$ version 9.2 (SAS Institute, Inc., Cary, NC). Fixed effects were herbicide treatments (both experiments), mowing (experiment one), pre-herbicide application mowing interval (experiment two), and season of herbicide application (experiment one), while experimental run and replicate were considered random as described by Carmer et al. (1989). Main effects and their interactions are presented accordingly, with precedent given to significant interactions of increasing magnitude (Steel et al. 1997) and means were separated according to Fisher's protected LSD $(\mathrm{P}=0.05)$.

\section{Results and Discussion}

Experiment One. Analysis of variance revealed a significant interaction between herbicide, application timing, and mowing regimen at 40 WAFT in experiment one (Table 2). Across application timings, herbicide activity varied most notably with clethodim and imazapic in routinely mowed plots. Fall-only clethodim applied to routinely mowed vaseygrass (10\% cover) decreased vaseygrass $19 \%$ compared to spring-only application (29\% cover; Table 3). The opposite trend was observed for imazapic, with cover decreasing 22\% with spring-only application (9\% cover) compared to fall-only application (31\% cover). Benefits of fall-plus-spring applications varied across herbicides. Spring-applied clethodim in routinely mowed plots did not improve vaseygrass control, as no differences were detected between fall-only ( $10 \%$ cover $)$ and fall-plusspring $(8 \%$ cover) timings, and both decreased cover more than spring-only application did (29\% cover); however, spring-only treatments were not repeated in space or time. Fall-plus-spring imazapic application to nonmowed vaseygrass decreased cover $(16 \%$ cover $)$ compared to spring-only application ( $31 \%$ cover); however, cover in routinely mowed plots that received fall-plus-spring or spring-only imazapic applications did not differ ( $9 \%$ and $7 \%$ cover, respectively). In nonmowed plots, fall-plus-spring metsulfuron + nicosulfuron application only improved vaseygrass cover reduction (26\% cover) compared to fall-only application (48\% cover). Excluding herbicide inputs, routine mowing reduced vaseygrass cover $17 \%$ to $20 \%$ compared to that of non-treated checks at 40 WAFT.

Table 2. Experiment one ANOVA for vaseygrass cover, with $\mathrm{P}$ values, for main effects and interactions. ${ }^{\text {a,b }}$

\begin{tabular}{lccc}
\hline \multirow{2}{*}{ Source of variation } & df & 40 WAFT & 52 WAFT \\
\hline & & & \\
Mowing & 1 & 0.3654 & 0.0577 \\
Season & 2 & 0.4955 & 0.1627 \\
Herbicide & 5 & 0.0955 & 0.0672 \\
$\mathrm{M} \times \mathrm{S}$ & 2 & 0.4311 & 0.3167 \\
$\mathrm{M} \times \mathrm{H}$ & 5 & 0.0002 & $<0.001$ \\
$\mathrm{~S} \times \mathrm{H}$ & 10 & 0.3807 & 0.0753 \\
$\mathrm{M} \times \mathrm{S} \times \mathrm{H}$ & 10 & 0.0003 & $<0.001$ \\
\hline
\end{tabular}

a Abbreviations: M, mowing; S, season; $H$, herbicide; df, degrees of freedom; WAFT, weeks after fall treatment.

b Two experimental runs conducted on a roadside in Duplin County, NC.

${ }^{\mathrm{c}}$ Cover visually estimated on a $0 \%$ (no cover) to $100 \%$ (complete cover) scale.

${ }^{\mathrm{d}}$ Fall applications October 16, 2012 and October 1, 2013; spring applications June 17, 2013 and June 18, 2014.

e Spring-only application evaluated only in run two. 
Table 3. Herbicide-by-application timing-by-mowing regimen interaction on vaseygrass cover 40 weeks after fall treatment. ${ }^{\text {a,b }}$

\begin{tabular}{|c|c|c|c|c|c|c|c|}
\hline \multirow[b]{2}{*}{ Herbicide $^{\mathrm{e}}$} & \multirow[b]{2}{*}{$\mathrm{g}$ ai ha ${ }^{-1}$} & \multicolumn{2}{|c|}{ Fall-only } & \multicolumn{2}{|c|}{ Fall-plus-spring } & \multicolumn{2}{|c|}{- Spring-only } \\
\hline & & Mowed & Nonmowed & Mowed & Nonmowed & Mowed & Nonmowed \\
\hline Clethodim & 280 & 10 & 15 & 8 & 11 & 29 & 25 \\
\hline $\mathrm{FOR}+\mathrm{HAL}+\mathrm{THI}$ & $44+69+22$ & 27 & 44 & 29 & 34 & 47 & 23 \\
\hline Imazapic & 140 & 31 & 29 & 7 & 16 & 9 & 31 \\
\hline $\mathrm{MET}^{1}+\mathrm{NIC}$ & $16+59$ & 38 & 48 & 30 & 26 & 30 & 38 \\
\hline Sulfosulfuron & 105 & 26 & 35 & 19 & 29 & 23 & 38 \\
\hline Non-treated & - & 33 & 50 & 31 & 51 & 38 & 58 \\
\hline
\end{tabular}

${ }^{\text {a }}$ Abbreviations: FOR, foramsulfuron; HAL, halosulfuron; THI, thiencarbazone; MET, metsulfuron; NIC, nicosulfuron.

b Two experimental runs conducted on a roadside in Duplin County, NC.

${ }^{\text {c }}$ Fall applications October 16, 2012 and October 1, 2013; spring applications June 17, 2013 and June 18, 2014.

d Spring-only application evaluated only in run two.

e All herbicide applications included a nonionic surfactant at $0.25 \% \mathrm{v} / \mathrm{v}$.

${ }^{\mathrm{f}}$ Cover visually estimated on a $0 \%$ (no cover) to $100 \%$ (complete cover) scale.

Similarly, ANOVA revealed a significant interaction between herbicide, application timing, and mowing regimen 52 WAFT (Table 2). With single applications, clethodim provided maximum vaseygrass cover reduction compared to other herbicides when applied fall-only in routinely mowed (7\% cover) and nonmowed $(16 \%$ cover) plots (Table 4$)$. Vaseygrass cover when treated with any other herbicide treatment in the fall was not different from that in routinely mowed plots. In nonmowed plots, vaseygrass cover was variable and control was unacceptably low $(<60 \%$ cover reduction), except for those plots treated with clethodim. Timing of clethodim application affected vaseygrass cover, with greater cover following spring-only applications to routinely mowed $(20 \%$ cover) and nonmowed ( $40 \%$ cover) plots compared to fall-only routinely mowed ( $7 \%$ cover) and nonmowed (16\% cover) plots. Spring-only imazapic and metsulfuron + nicosulfuron application decreased cover relative to the non-treated plots, most notably when applied in conjunction with routine mowing ( $11 \%$ to $14 \%$ cover). Additionally, fall-plus-spring imazapic and metsulfuron + nicosulfuron decreased vaseygrass cover to $\leq 7 \%$. Although metsulfuron + nicosulfuron did not provide acceptable vaseygrass control at 40 WAFT, fall-plus-spring and spring-only application provided equal or greater vaseygrass cover reductions than clethodim and imazapic at 52 WAFT across mowing regimens. This may have been due to an inadequate period of time between the spring herbicide applications and data collection at 40 WAFT (approximately $4 \mathrm{wk}$ after spring treatment). Routine mowing affected vaseygrass cover at 52 WAFT. Excluding fall-only

Table 4. Herbicide-by-application timing-by-mowing regimen interaction on vaseygrass cover 52 weeks after fall treatment. ${ }^{\text {ab }}$

\begin{tabular}{|c|c|c|c|c|c|c|c|}
\hline Herbicide $^{e}$ & $\mathrm{~g}$ ai ha ${ }^{-1}$ & \multicolumn{2}{|c|}{ Fall-onlyc } & \multicolumn{2}{|c|}{ Fall-plus-spring } & \multicolumn{2}{|c|}{- Spring-only } \\
\hline & & & & 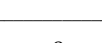 & & & \\
\hline Clethodim & 280 & 7 & 16 & 8 & 22 & 20 & 40 \\
\hline Imazapic & 140 & 24 & 44 & 7 & 24 & 14 & 45 \\
\hline $\mathrm{MET}+\mathrm{NIC}$ & $16+59$ & 34 & 51 & 6 & 12 & 11 & 25 \\
\hline Sulfosulfuron & 105 & 29 & 44 & 14 & 31 & 20 & 43 \\
\hline Non-treated & - & 30 & 63 & 24 & 59 & 28 & 60 \\
\hline
\end{tabular}

a Abbreviations: FOR, foramsulfuron; HAL, halosulfuron; THI, thiencarbazone; MET, metsulfuron; NIC, nicosulfuron.

b Two experimental runs conducted on a roadside in Duplin County, NC.

c Fall applications October 16, 2012 and October 1, 2013; spring applications June 17, 2013 and June 18, 2014.

d Spring-only application evaluated only in run two.

e All herbicide applications included a nonionic surfactant at $0.25 \% \mathrm{v} / \mathrm{v}$.

${ }^{\mathrm{f}}$ Cover visually estimated on a $0 \%$ (no cover) to $100 \%$ (complete cover) scale. 
clethodim and fall-plus-spring metsulfuron + nicosulfuron, all herbicide and timing combinations decreased vaseygrass cover more in routinely mowed plots than in nonmowed plots. Additionally, mowing was required to reduce vaseygrass cover to $<10 \%$ in treated plots. Lastly, routine mowing reduced vaseygrass cover $25 \%$ to $33 \%$ in non-treated plots, suggesting that mowing may have utility as a stand-alone cultural practice.

Results from this experiment generally agree with previous research pertaining to the relationship between herbicide application timing, plant growth stage, and season. Johnson and Norsworthy (2014) reported that 4 wk following nicosulfuron $(35 \mathrm{~g}$ ai $\mathrm{ha}^{-1}$ ) application, johnsongrass [Sorghum halepense (L.) Pers.] was $72 \%$ controlled when applications were made at $15-\mathrm{cm}$ plant heights, but were $17 \%$ controlled when applications were made at $60-\mathrm{cm}$ plant heights. Ruffner and Barnes (2010) reported that spring-applied imazapic $\left(210 \mathrm{~g}\right.$ ai ha $\left.{ }^{-1}\right)$ reduced tall fescue [Lolium arundinaceum (Schreb.) S.J. Darbyshire] cover more than spring-applied clethodim did $\left(230 \mathrm{~g}\right.$ ai $\left.\mathrm{ha}^{-1}\right)$. Reducing vaseygrass cover to less than $10 \%$ with metsulfuron + nicosulfuron required fall and spring application, which is consistent with current herbicide label verbiage, which states that two applications may be required for acceptable control (Anonymous 2015). Additionally, Israel et al. (2012) reported that two applications of metsulfuron + nicosulfuron were required to acceptably control the warm-season, perennial grass knotroot foxtail [Setaria parviflora (Poir.) Kerguélen]. Within the confines of this experiment, an explanation of the varying results from clethodim fall and spring applications cannot be determined. Although all herbicides did not behave similarly, vaseygrass may have been more susceptible to clethodim in the fall as the weed approached dormancy. Previous research has shown that dallisgrass (Paspalum dilatatum Poir.) response to select herbicides varies by season (Anonymous 2013; Caponio and Quarín 1990). Brosnan et al. (2010) reported $80 \%$ to $88 \%$ dallisgrass control $55 \mathrm{~d}$ after treatment following fluazifop application $\left(105 \mathrm{~g}\right.$ ai ha $\left.{ }^{-1}\right)$ in April; however, control decreased to less than $24 \%$ when fluazifop was applied in May or June. Elmore et al. (2013) also reported superior dallisgrass control at $365 \mathrm{~d}$ after treatment from fluazifop application $\left(105 \mathrm{~g} \mathrm{ha}^{-1}\right)$ in April $(79 \%$ to $83 \%$ control) compared to May or June (33\% to
$66 \%$ control). Additionally, the authors reported $88 \%$ to $93 \%$ control when application was delayed to September, which parallels findings regarding fall clethodim application for vaseygrass control in the research presented here.

Results from this experiment also generally agree with previous research pertaining to mowing effects on the establishment of select invasive plants. Derr (2008) reported that mowing every 2, 4, or $8 \mathrm{wk}$ controlled common reed [Phragmites australis (Cav.) Trin. ex Steud.] 93\%, 81\%, and 69\%, respectively, while Aigner and Woerly (2011) reported 48\% barb goatgrass (Aegilops triuncialis L.) control as a result of mowing. Previous research has shown that decreasing canopy height adversely affects vaseygrass spread. Newman et al. (2003) reported that vaseygrass cover decreased $9 \%$ over $2 \mathrm{yr}$ when maintained at $20 \mathrm{~cm}$, while it increased $4 \%$ when maintained at $40 \mathrm{~cm}$. Parr and Way (1988) concluded that roadside mowing affects plant competition by reducing vigor of taller-growing species through altering growth habits and root-to-shoot ratios, coupled with increasing light penetration at the soil surface which aids prostrate species growth.

Experiment Two. At 4 WAT in experiment two, ANOVA revealed a significant interaction between the effects of herbicide and pre-herbicide application mowing interval on vaseygrass seedhead counts, and a main effect of herbicide on vaseygrass height (Table 5). Across 6, 3, and 2 wk pre-herbicide application mowing intervals, clethodim and imazapic reduced vaseygrass seedhead production and height at 4 WAT, while treatment with metsulfuron + nicosulfuron had results similar to those of the non-treated plots (Table 6). In general, differences in seedhead counts between the herbicide-treated plots and the non-treated plots decreased as mowing interval decreased. This is likely due to herbicidal activity (as seen when comparing clethodim and imazapic with metsulfuron + nicosulfuron at 6, 4, 3, and 2 WBT), coupled with varying time for growth between mowing and data collection at 4 WAT for the various mowing intervals. More specifically, plots mowed 6 WBT grew for a 10-wk period between cutting and data collection at 4 WAT, while plots mowed 0 WBT only had 4 wk to grow before the data collection at 4 WAT. Within clethodim and imazapic treatments, mowing interval did not affect seedhead production, with counts ranging from 1 to $8 \mathrm{~m}^{-2}$. 
Table 5. Experiment two analysis of variance for vaseygrass seedheads, height, and cover with $P$ values for main effects and interactions. ${ }^{\text {ab,c }}$

\begin{tabular}{|c|c|c|c|c|c|c|c|c|c|}
\hline \multirow[b]{2}{*}{ Source of variation } & \multirow[b]{2}{*}{ df } & \multicolumn{3}{|c|}{-Seedheads $\mathrm{m}^{-2}$} & \multicolumn{3}{|c|}{$\longrightarrow$ Height $(\mathrm{cm}) \longrightarrow$} & \multicolumn{2}{|c|}{$-\%$ Cover $^{\mathrm{d}}$} \\
\hline & & 4 WAT & 40 WAT & 52 WAT & 4 WAT & 40 WAT & 52 WAT & 40 WAT & 52 WAT \\
\hline Herbicide $^{\mathrm{e}}$ & 5 & $<0.0001$ & $<0.0001$ & 0.002 & $<0.0001$ & $<0.0001$ & 0.0088 & $<0.0001$ & $<0.0001$ \\
\hline $\mathrm{MI} \times \mathrm{H}$ & 25 & $<0.0001$ & 0.5371 & 0.6488 & 0.4836 & 0.4851 & 0.6214 & 0.5690 & 0.5108 \\
\hline
\end{tabular}

${ }^{\text {a }}$ Abbreviations: MI, mowing interval; H, herbicide; df, degrees of freedom; WAT, week after treatment.

b Two experimental runs conducted on a roadside in Craven County, NC.

${ }^{c}$ Height and seedhead counts were averaged over three recordings per plot.

d Cover visually estimated on a $0 \%$ (no cover) to $100 \%$ (complete cover) scale.

e Applications September 18, 2013 and September 19, 2014.

Across data collected 40 and 52 WAT, ANOVA revealed a significant main effect of herbicide, while pre-herbicide application mowing interval did not affect vaseygrass growth as measured by visual cover, height (excluding $40 \mathrm{WAT}$ ), and seedhead count (Table 5). At 40 WAT, clethodim, imazapic, and metsulfuron + nicosulfuron reduced vaseygrass cover and height compared to the non-treated plots (Table 7). Of these herbicides, clethodim and imazapic reduced cover by $24 \%$ to $25 \%$ and reduced height by 15 to $16 \mathrm{~cm}$ compared to the non-treated plots, while metsulfuron + nicosulfuron only reduced cover by $7 \%$ and height by $5 \mathrm{~cm}$. These results suggest that clethodim and imazapic may reduce roadside mowing requirements within a season. Vaseygrass seedhead production had not uniformly resumed at 40 WAT. Following data collection at $40 \mathrm{WAT}$, research areas were mowed and allowed to regrow for a 12 -wk period.

ANOVA revealed a significant main effect of herbicide on vaseygrass cover and seedhead counts 52 WAT, while vaseygrass height did not differ between herbicide treatments (Table 5). At 52 WAT, plots receiving metsulfuron + nicosulfuron treatment did not have significantly different vaseygrass cover $(46 \%$ cover) or seedhead counts $(38$ seedheads $\mathrm{m}^{-2}$ ) than the non-treated control plots $\left(50 \%\right.$ cover, 46 seedheads $\mathrm{m}^{-2}$ ) (Table 7). Plots treated with imazapic and, most notably, clethodim, had decreased vaseygrass cover and seedhead counts compared to the non-treated plots, with $23 \%$ and $12 \%$ cover and 11 and 8 seedheads $\mathrm{m}^{-2}$, respectively. Surviving vaseygrass in clethodim and imazapic plots did not show any herbicide symptoms at 52 WAT,

Table 6. Herbicide-by-pre-herbicide application mowing interval interaction on vaseygrass seedhead counts and the main effect of herbicide on vaseygrass height, 4 weeks after treatment. ${ }^{\text {a-c }}$

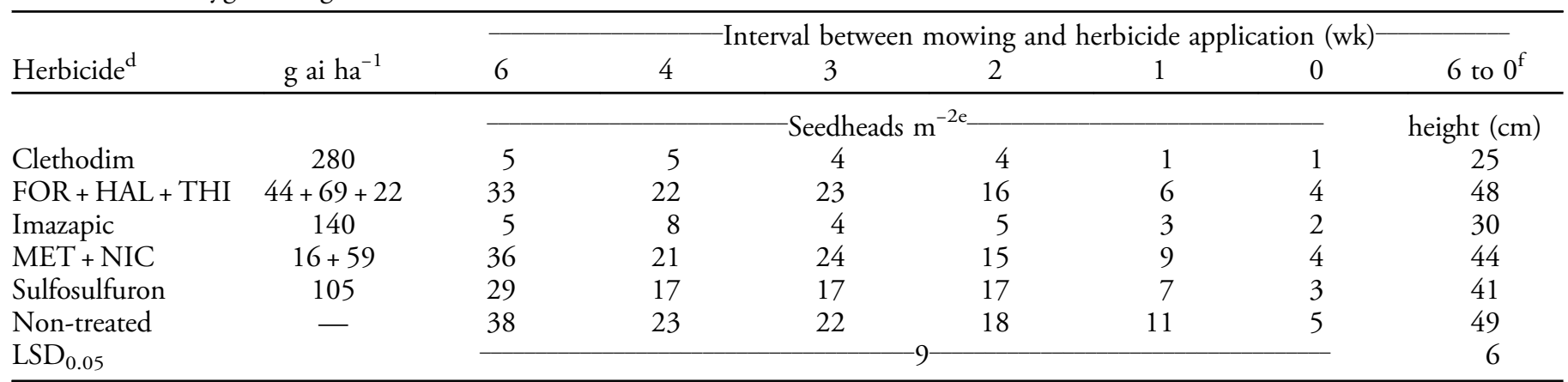

a Abbreviations: FOR, foramsulfuron; HAL, halosulfuron; THI, thiencarbazone; MET, metsulfuron; NIC, nicosulfuron.

b Two experimental runs conducted on a roadside in Craven County, NC.

c Applications September 18, 2013 and September 19, 2014.

d All herbicide applications included a nonionic surfactant at $0.25 \% \mathrm{v} / \mathrm{v}$.

e Height and seedhead counts were averaged over three recordings per plot.

${ }^{\mathrm{f}}$ Data pooled over PRE-herbicide application mowing interval. 
Table 7. Main effect of herbicide on vaseygrass cover, height, and seedhead counts 40 and 52 weeks after treatment. ${ }^{\text {a-d }}$

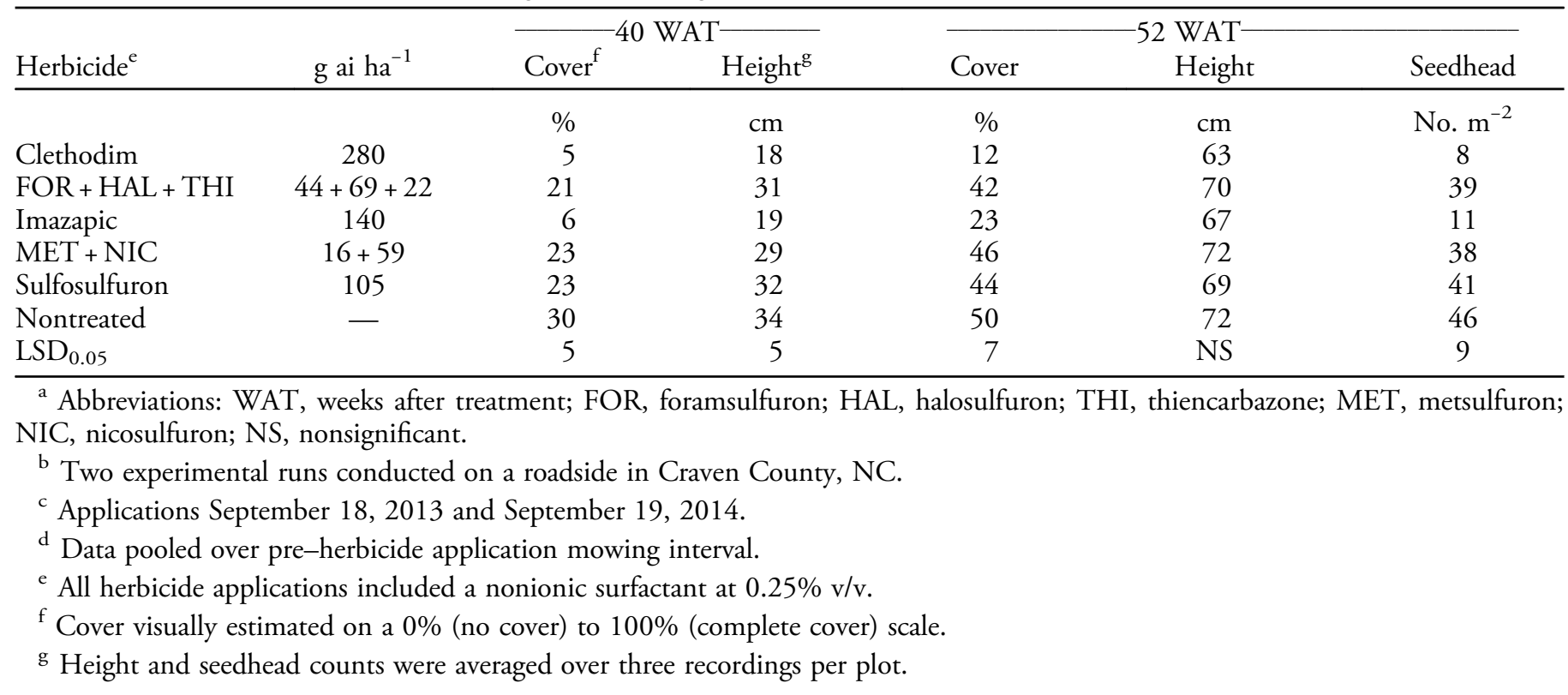

and seedhead reductions aligned with cover reductions. Furthermore, no differences in vaseygrass height were detected across herbicide treatments at this time point, which suggests that the control practices evaluated in this research would require multiple growing seasons to completely eradicate vaseygrass.

Overall, pre-herbicide application mowing interval did not affect herbicide activity on vaseygrass; however, this was likely due in part to generally poor control from foramsulfuron + halosulfuron + thiencarbazone and sulfosulfuron. Additionally, spring imazapic and metsulfuron + nicosulfuron application, which decreased vaseygrass cover in experiment one, were not included. Lastly, plots were not routinely mowed in experiment two, which may have improved imazapic and metsulfuron + nicosulfuron activity on vaseygrass. To focus on the effect of pre-herbicide application mowing interval on clethodim, the most efficacious fall-applied herbicide evaluated, data were analyzed separately for each herbicide. At 40 WAT, mowing vaseygrass 1 or 2 WBT with clethodim resulted in 1 to $2 \%$ cover, which generally outperformed mowing $0(6 \%)$ or from 3 to 6 WBT (3 to $11 \%$ ) (Table 8). The same trend was observed at 52 WAT: vaseygrass that was mowed 1 to 2 weeks before clethodim treatment ( 4 to $6 \%$ cover) resulted in superior control compared to mowing $0,3,4$, or 6 weeks before clethodim treatment $(13 \%, 14 \%$, $13 \%$, and $23 \%$, respectively). Although there was only a $10 \%$ difference in vaseygrass cover at 52 WAT when mowing occurred 2 or 3 WBCT, cover reduction relative to respective nontreated $(47 \%$ cover for both 2 and 3 WBCT) increased $21 \%$ from mowing 2 WBCT compared to 3 , suggesting the shorter period of time between mowing and treatment enhanced clethodim efficacy. These results agree with current clethodim label recommendations, which suggest allowing for perennial grass vegetation regrowth to $30 \mathrm{~cm}$ (excluding johnsongrass) following mowing to promote foliar clethodim uptake (Anonymous 2011a).

Results from this research indicate that vaseygrass eradication from North Carolina roadsides may require management inputs over multiple growing seasons. Overall, routine mowing had a pronounced effect on reducing vaseygrass cover as a stand-alone cultural practice, and in most cases improved herbicide efficacy. While mowing decreased vaseygrass cover $55 \%$ at $52 \mathrm{WAT}$, in practice mowing is difficult in many areas with vaseygrass infestations due to issues associated with equipment operation in poorly drained soils. Under these circumstances, herbicide inputs can serve as a viable vaseygrass management input; however, efficacy varies based on herbicide and application timing. Optimal herbicide efficacy was obtained when clethodim was applied in the fall, and when imazapic and metsulfuron + nicosulfuron were applied in the spring. Additionally, metsulfuron + nicosulfuron applied in fall and spring to nonmowed vaseygrass reduced cover $80 \%$ at 52 WAT, 
Table 8. Clethodim application-by-pre-herbicide application mowing interval interaction on vaseygrass cover 40 and 52 weeks after treatment. ${ }^{\text {a-d }}$

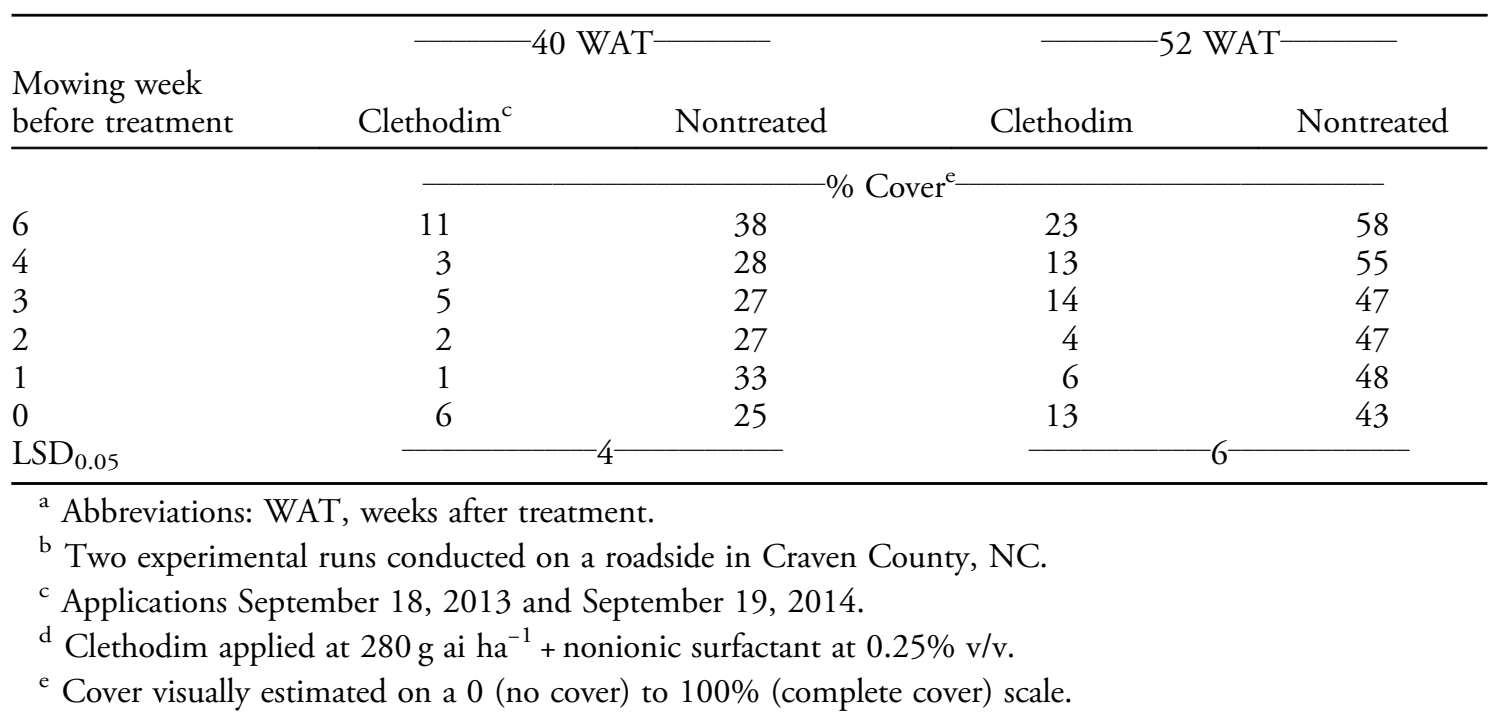

while clethodim and imazapic required mowing to achieve comparable cover reductions. Herbicides can be used alternately based on application timing to optimize vaseygrass control, and this practice will also serve as an herbicide resistance prevention measure due to the varying modes of action between clethodim (inhibition of acetyl coenzyme A carboxylase) and imazapicl metsulfuron + nicosulfuron (inhibition of acetolactate synthase) (Shaner 2014). Through 2015, there were 47 and 157 plant species worldwide with reported resistance to acetyl coenzyme A carboxylase and acetolactate synthase inhibitors, respectively (Heap 2015).

Vaseygrass primarily encroaches bahiagrass and/or centipedegrass on roadsides in North Carolina, and it should be noted that the herbicides that were found to provide acceptable control also pose tolerance concerns to the aforementioned species. Ferrell et al. (2003) reported that clethodim application $\left(280 \mathrm{~g} \mathrm{ha}^{-1}\right)$ resulted in $26 \%$ to $50 \%$ centipedegrass injury from 2 to 6 WAT in one experimental run; however, less than $12 \%$ injury was observed the following year. Centipedegrass is tolerant to imazapic and metsulfuron at the evaluated application rates; however, research to date is inconclusive on metsulfuron + nicosulfuron (Anonymous 2011c, 2016). Bahiagrass is sensitive to clethodim and imazapic at the evaluated application rates, while reports of metsulfuron sensitivity are inconclusive (Alabama Extension 2016; Anonymous 2011c; Bunnell et al. 2003). Bunnell et al. (2003) reported that the metsulfuron application rate required to reduce bahiagrass growth $50 \% 6$ WAT was $9.5 \mathrm{~g} \mathrm{ha}^{-1}$ in one experimental run; however, $40.2 \mathrm{~g} \mathrm{ha}^{-1}$ was required the following year. Ultimately, rights-of-way managers should be cognizant of potential injury to desirable turfgrass species following herbicide application for vaseygrass control, which may reduce the competitive ability of desired species and create more conducive conditions for vaseygrass and other weed species to encroach.

When routine mowing operations are part of a vegetation management plan, timing this cultural practice with an herbicide application may improve vaseygrass control. This was observed following clethodim application, and maximum cover reductions were consistent with current label recommendations regarding perennial grass height at application. However, mowing interval did not affect vaseygrass cover following imazapic and metsulfuron + nicosulfuron treatments. This pattern should be further investigated to confirm that this was not due to application at a suboptimal fall timing. Future research should evaluate treatment regimens including clethodim and imazapic or metsulfuron + nicosulfuron at fall and spring timings, respectively, and PRE herbicides for vaseygrass seed bank reduction.

\section{Acknowledgements}

This research was funded by, and conducted in collaboration with, the North Carolina Department of Transportation Roadside Environmental Unit. The authors wish to thank all individuals, notably 
Kevin Clemmer, Greg Rayburn, and Derek Smith, who assisted with research site selection and subsequent management inputs to preserve areas.

\section{Literature Cited}

Aigner PA, Woerly RJ (2011) Herbicides and mowing to control barb goatgrass (Aegilops triuncialis) and restore native plants in serpentine grasslands. Invasive Plant Sci Manag 4:448-457

Alabama Extension (2016) Commercial Turf and Lawns: Chemical Weed Control Recommendations for 2016. http://www.aces. edu/pubs/docs/I/IPM-0022/IPM-0022.pdf. Accessed August 11, 2016

Anonymous (2011a) Intensity ${ }^{\circledR}$ Post-Emergence Grass Herbicide product label. Loveland Publication No. 081910 V1D 09G10. Greeley, CO: Loveland Products. 42 p

Anonymous (2011b) Outrider ${ }^{\circledR}$ herbicide product label. Monsanto Publication No. 71014J5-14. St. Louis, MO: Monsanto. 8 p

Anonymous (2011c) Plateau $^{\circledR}$ herbicide product label. BASF Publication No. NVA 2011-04-126-0007. Research Triangle Park, NC: BASF. $15 \mathrm{p}$

Anonymous (2013) Tribute $^{\circledR}$ Total herbicide product label. Bayer Publication No. 80520492. Research Triangle Park, NC: Bayer Environmental Science. $11 \mathrm{p}$

Anonymous (2015) Pastora ${ }^{\circledR}$ herbicide product label. DuPont Publication No. SL - 1931120814 02-05-15. Wilmington, DE: DuPont. $15 \mathrm{p}$

Anonymous (2016) Escort $^{\circledR}$ herbicide product label. Bayer Publication No. 84122394. Research Triangle Park, NC: Bayer Environmental Science. $23 \mathrm{p}$

Ansong M, Pickering C, Arthur JM (2015) Modelling seed retention curves for eight weed species on clothing. Austral Ecology 40:765-774

Brosnan JT, Breeden GK, Elmore MT, Zidek JM (2010) Early and late postemergence control of dallisgrass (Paspalum dilatatum Poir.) in tall fescue. Appl Turfgrass Sci DOI: 10.1094/ATS-2010-0312-02-RS

Bryson CT, DeFelice MS, Evans AW (2009) Weeds of the South. Athens, GA: University of Georgia Press. p 402

Bunnell BT, Baker RD, McCarty LB, Hall DW, Colvin DL (2003) Differential response of five bahiagrass (Paspalum notatum) cultivars to metsulfuron. Weed Technol 17:550-553

Caponio I, Quarín CL (1990) Intra- and interspecific hybridization between dallisgrass and vaseygrass. Crop Sci 30:362-364

Carmer SG, Nyquist WE, Walker WM (1989) Least significant differences for combined analyses of experiments with two- or three-factor treatment designs. Agron J 81:665-672

Derr JF (2008) Common reed (Phragmites australis) response to mowing and herbicide application. Invasive Plant Sci Manag $1: 12-16$

Elmore MT, Brosnan JT, Mueller TC, Horvath BJ, Kopsell DA, Breeden GK (2013) Seasonal application timings affect dallisgrass (Paspalum dilatatum) control in tall fescue. Weed Technol 27:557-564

Ferrell J, Unruh B, Kruse J (2009) A Guide for Roadside Vegetation Management. Tallahassee, FL: Florida Department of Transportation. $94 \mathrm{p}$
Ferrell JA, Murphy TR, Vencill WK, Guerke WR (2003) Effects of postemergence herbicides on centipedegrass seed production. Weed Technol 17:871-875

Heap I (2015) The International Survey of Herbicide Resistant Weeds. http://weedscience.org/. Accessed December 31, 2015

Israel TD, Rhodes GN Jr, Via JD, Muller B (2012) Knotroot Foxtail, Pasture Weed Factsheet. Knoxville, TN: University of Tennessee Extension. $2 \mathrm{p}$

Johnson DB, Norsworthy JK (2014) Johnsongrass (Sorghum halepense) management as influenced by herbicide selection and application timing. Weed Technol 28:142-150

Louisiana Department of Transportation (2000) Policy for Roadside Vegetation Management. http://wwwsp.dotd.la.gov/ Inside_LaDOTD/Divisions/Engineering/Misc\%20Documents/ Policy\%20For\%20Roadside\%20Vegetation\%20Management.pdf. Accessed December 26, 2015

Minnesota Department of Transportation (2008) Best Practices Handbook for Roadside Vegetation Management. St. Paul, MN: Minnesota Department of Transportation. $17 \mathrm{p}$

Missouri Department of Transportation (2003) Roadside Vegetation Management. http://www.modot.org/services/documents/ roadsidevegmgt5-03.pdf. Accessed December 26, 2015

[NCHRP] National Cooperative Highway Research Program (2005) Integrated Roadside Vegetation Management: A Synthesis of Highway Practice. Washington, DC: Transportation Research Board. $89 \mathrm{p}$

Newman YC, Sollenberger LE (2005) Grazing management and nitrogen fertilization effects on vaseygrass persistence in limpograss pastures. Crop Sci 45:2038-2043

Newman YC, Sollenberger LE, Fox AM, Chambliss CG (2003) Canopy height effects on vaseygrass and bermudagrass spread in limpograss pastures. Agron J 95:390-394

Ohio Turnpike Commission (2003) Best Management Practice: Modification of the OTC's Mowing Program. http://www. ohioturnpike.org/docs/default-source/storm-water/stormwaterprogram mowing_article.pdf?sfvrsn=2. Accessed December 26, 2015

Parr TW, Way JM (1988) Management of roadside vegetation: the long-term effects of cutting. J Appl Ecol 25:1073-1087

Ruffner ME, Barnes TG (2010) Natural grassland response to herbicides and application timing for selective control of tall fescue, an invasive cool-season grass. Invasive Plant Sci Manag 3:219-228

Sanders DE, Strahan RE, Gentry GT (2001) Weed control with Plateau (imazapic) and Oasis (imazapic +2,4-D) in hybrid bermudagrass hay production. Page 74 in Proceedings of the 54th Southern Weed Science Society Meeting. Biloxi, MS: Southern Weed Science Society

Shaner DL (2014) Herbicide Handbook. 10th edn. Champaign, IL: Weed Science Society of America. Pp 104-105, 256-257, 311-312, 323-324

Steel RD, Torrie JH, Dickey DA (1997) Principles and Procedures of Statistics: A Biometrical Approach. 3rd edn. New York, NY: WCB McGraw-Hill. Pp 353-384

[USDA] United States Department of Agriculture (2015) Natural Resources Conservation Service, Vasey's Grass Plant Profile. http://plants.usda.gov/core/profile?symbol=PAUR2. Accessed December 24, 2015

Zartman RE, McKenney CB, Wester DB, Sosebee RE, Borrelli JB (2013) Precipitation and mowing effects on highway rights-ofway vegetation height and safety. Landscap Ecol 9:121-129 